\title{
Fora do jogo: \\ a experiência dos negros na classe média brasileira*
}

\begin{abstract}
Angela Figueiredo**
Resumo

Abordo neste texto o significado da mobilidade social para empresários negros que fazem parte da classe média, a partir do relato das trajetórias de mobilidade e do significado da cor nesse processo. Ao contrário da maioria dos estudos clássicos sobre o tema, que viam na mobilidade social dos negros um exemplo contundente da não existência do preconceito de cor no Brasil, destaco na análise a forma como o preconceito e a discriminação são percebidos pelos entrevistados. Mas ainda que a maioria deles tenha relatado terem sido vítimas do preconceito racial, as respostas variam muito e nenhum deles relatou ter recorrido à justiça. Por este motivo, tenho insistido no fato de que o reconhecimento ou a percepção que o próprio indivíduo tem acerca de ser alvo do preconceito racial não se traduz, necessariamente, na tomada de uma atitude que consideremos eficaz ou politicamente relevante no combate ao racismo.
\end{abstract}

Palavras-chave: Racismo, Ascensão Social, Classe Média Negra.

\footnotetext{
* Recebido para publicação em agosto de 2004, aceito em outubro de 2004.

*** Pesquisadora do ISC/MUSA/UFBA e pesquisadora associada da Fábrica de idéias-CEAO/UFBA, Salvador-BA, Brasil. angelafigueiredo@yahoo.com
}

cadernos pagu (23), julho-dezembro de 2004, pp.199-228. 
Fora do jogo

\author{
Out of the Game: \\ Brazilian Black Middle Class Experiences
}

\begin{abstract}
The article deals with the meaning of social mobility for black entrepreneurs and businessmen that can be considered as part of a middle class. The metodology consists of the study of life careers and the place of colour therein. In spite of most canonical studies pointing out to the simple fact of social mobility for Black Brazilians as the best piece of evidence of the absence of a colour bar in Brazil, I single out the way in which such bar is perceived by the informants. However, even though most of them have experienced racial discrimination, their response to it varies a lot and none ever lodged a legal complaint. My argument is that individual recognition or perception of racial discrimination do not conflate straightforwardly with an actual and effective political stance in the struggle against racism.
\end{abstract}

Key Words: Racism, Social Mobility, Black Middle Class. 
Angela Figueiredo

Com um jeito um tanto hesitante aproximam-se de mim, olham-me com curiosidade ou com compaixão e então, em vez de perguntarem diretamente, como é a sensação de ser um problema, dizem: Na minha cidade conheço um excelente homem de cor; [...] Eu então sorrio, ou me interesso, ou reduzo o calor da minha raiva, conforme a ocasião. Quanto à pergunta real: Como é a sensação de ser um problema? Raramente respondo uma palavra sequer. ${ }^{1}$

Sabemos do desconforto frente a situações nas quais nós negros somos notados, admoestados, num misto de curiosidade e espanto por parte de observadores que são surpreendidos pela presença negra em seu meio. Nas minhas pesquisas, vários entrevistados mencionaram que são olhados com curiosidade quando participam de atividades sociais relacionadas à classe média, e com desconfiança quando querem adquirir ou desfrutar dos bens sociais e simbólicos associados a pessoas de poder aquisitivo mais elevado. ${ }^{2} \mathrm{E}$, mesmo quando de posse desses bens, há o constrangimento provocado pelas diversas perguntas acerca da efetiva possibilidade de que aqueles indivíduos negros venham a ser os verdadeiros proprietários de determinados bens, que tenham suficientes recursos financeiros para quitar uma dívida adquirida, ou que possam freqüentar espaços sociais identificados com a classe média.

Tudo isso cria uma tensão adicional no cotidiano das pessoas negras com poder aquisitivo mais elevado, que sempre são vistas como estando "fora do lugar" sociologicamente construído e simbolicamente determinado; em outras palavras, eles estão pagando um alto preço exatamente por estarem "fora do lugar". Uma das entrevistadas mencionou um exemplo que ela considerava bastante comum: quando se dirigiu a uma loja para

1 Du BoIs, W. E. B. As almas da gente negra. Rio de Janeiro, Lacerda Editores, 1999, p.52.

2 Os dados apresentados neste texto fazem parte da pesquisa que realizei em Salvador com os empresários negros no primeiro semestre de 2000. 
Fora do jogo

comprar sapatos, indagou ao vendedor se havia um número específico daquele modelo de sapato exposto na vitrine; o vendedor então lhe disse o preço do sapato, mas não sobre a numeração, pergunta que ela havia feito. Reconhecendo a estratégia do vendedor, pondo em dúvida a sua capacidade de compra, a entrevistada quis mostrar a ele que não poderia duvidar do seu poder aquisitivo, mas em vez de penalizá-lo, não comprando o objeto, ela optou por comprar muito mais do que desejava. De acordo com a sua interpretação, ela deu um "tapa sem mão" no vendedor, mostrando que ele não poderia agir assim só pelo fato de se tratar de uma cliente negra. Em se tratando do consumo, esta tem sido uma estratégia bastante freqüente entre os entrevistados. Por este motivo, tenho insistido no fato de que o reconhecimento ou a percepção de que o próprio indivíduo tem acerca de ser alvo do preconceito racial, não se traduz, necessariamente, na tomada de uma atitude que consideremos eficaz ou politicamente relevante no combate ao racismo.

Esta desconfiança com relação aos negros de classe média resulta, a meu ver, de três importantes fatores: 1) do baixo percentual de negros em posições sociais mais elevadas; 2) da construção social sobre o negro que o coloca sempre em uma posição econômica e simbólica inferior à dos brancos; e 3) da construção sócio-antropológica da categoria negro que tem construído uma incompatibilidade entre ser negro $e$ poder desfrutar dos bens associados à modernidade. Isto significa que há uma ressonância ou uma interpenetração das construções sociais originalmente formuladas em diferentes lugares e por diferentes agentes, ou seja, as ciências sociais e o senso comum estão em perfeita consonância no que se refere ao entendimento sobre o "lugar dos negros" na sociedade brasileira.

A dificuldade em refletir sobre a estratificação social no interior dos grupos étnico-raciais não diz respeito apenas à literatura que aborda a temática das relações raciais e da identidade negra; ao contrário, quando a ênfase é posta nos 
grupos étnicos/raciais, há uma tendência de que a análise seja homogeneizante em termos de classe. Alguns autores que tratam da temática da etnicidade em outros contextos têm alertado para a importância das diferenças geracionais e de gênero nas estratégias de mobilidade, na relação com as práticas identificadas como tradicionais e no relacionamento dos membros das minorias com a sociedade mais abrangente. ${ }^{3}$ Estes textos têm oferecido importantes pistas para a reflexão sobre a diferenciação no interior dos grupos.

Referindo-se à realidade brasileira, e mais especificamente soteropolitana, Sansone, no artigo "Pai preto filho negro"4, demonstra que a diferença geracional entre pais e filhos implica não só a utilização de termos diferenciados na auto-classificação da cor, como na postura diante do mercado de trabalho. Os filhos, mais escolarizados do que os pais, se auto-classificam como negros e não aceitam determinados trabalhos manuais através dos quais seus pais tinham sido inseridos no mercado de trabalho.

Tendo como referência as questões colocadas acima, proponho neste artigo abordar algumas questões relativas ao significado da mobilidade social dentre os negros no contexto contemporâneo. Considerando a relativa ausência de pesquisas sobre o tema, faz-se necessário mencionar que a classe média negra brasileira é composta majoritariamente por indivíduos da primeira geração de ascendentes, na maioria das vezes filhos de trabalhadores manuais que não herdaram bens imóveis, portanto, sobrevivem exclusivamente dos salários, e nem foram socializados num ambiente de classe média, o que poderíamos nos referir ao habitus de classe. ${ }^{5}$ Refiro-me, portanto, à classe média de um

3 VermeUlen, Hans. Imigração, integração e a dimensão política da cultura. Lisboa, Edições Colibri, 2001.

4 SANSONE, Livio. Pai preto, filho negro: Cor e diferença de geração. Estudos Afro-Asiáticos, n 25, 1993, pp.7-98.

5 Defino a classe média a partir de alguns critérios objetivos tais como, escolaridade, ocupação e renda. Em texto anterior problematizei o uso da noção de classe média quando aplicada aos negros e da expressão classe média negra, 
Fora do jogo

grupo subalternizado, instável, incipiente e que encontra muitas dificuldades em manter-se na posição de classe. ${ }^{6}$

\section{Mobilidade social e "inserção no mundo dos brancos"}

Ainda que haja diferenças nos resultados e nas abordagens das pesquisas realizadas a partir dos anos 1930 sobre a mobilidade ascendente dos negros, a maioria delas é unânime em constatar que a ascensão social dos negros só se efetivava a partir das relações sociais e de dependência mantidas entre negros e brancos - isto é, para ascender socialmente, os negros deveriam ser apadrinhados pelos brancos, casarem-se com um(a) branco(a) ou se comportarem, na forma de vestir e falar, semelhantes aos brancos.

Com relação ao apadrinhamento, Azevedo observa:

É importante registrar que, até este momento, o principal canal de ascensão social, através do qual grande número de pretos e mestiços têm adquirido status elevado, é a educação no duplo sentido de boas maneiras e de uma instrução de elevado nível, além da adesão aos mores $e$ concepção da cultura dominante, o que, em última análise, é um problema da aculturação ou de mais completa integração das massas de cor na sociedade dominante.[...] Um dos mecanismos que facilitam essa integração é a proteção $e$ a ajuda que muitos padrinhos $e$ madrinhas proporcionam aos seus afilhados de cor, educando-os em suas próprias casas ou, pelo menos, obtendo-lhes empregos ou encaminhando-os aos estudos secundário e superior $e$, muitas vezes, continuando a orientá-los e protegê-los [...]. ${ }^{7}$

ver FigueIREDO, A. Novas elites de cor: estudo sobre os profissionais liberais negros de Salvador. São Paulo, Annablume/UCAM, 2002.

${ }^{6}$ ID., IB. Novas elites de cor... Op. cit. e A classe média negra não vai ao paraíso: trajetórias, perfis e identidade entre os empresários negros. Tese de doutorado, Rio de Janeiro, IUPERJ, 2003.

7 AZEVEDO, Thales de. As Elites de Cor numa cidade brasileira: um estudo sobre 
Jéferson Bacelar considera que pertencer ao setor público no passado era indicativo das boas relações que pretos e pardos mantinham com os brancos, revelando tanto o clientelismo existente na contratação e nas relações de trabalho quanto o apadrinhamento de negros por famílias brancas:

Pertencer ao serviço público, mesmo nas posições subalternas, já denotava alguma forma de prestígio, indicando, no mínimo, as boas relações com os donos do poder político (...) na medida que a inserção se dava pelo clientelismo e apadrinhamento. ${ }^{8}$

Nesse sentido, a relação desigual entre negros e brancos no passado não implicou numa absoluta ausência de acesso dos negro-mestiços a postos mais elevados na hierarquia social, porém, o ingresso ocorria por uma estrutura de merecimento familiar, em que a afeição, a fidelidade aos reconhecidos como superiores, $e$ a confiança na manutenção desses critérios poderia tornar um agente, a princípio pobre e negro-mestiço, apto a ter acesso a bens culturais raros para a maioria da população. Como essa estrutura distributiva é dependente de investimentos construídos num plano de afetividade familiar, o processo de distribuição de bens simbólicos tende a reforçar disposições individualizantes em agentes oriundos de setores dominados.

As estruturas de poder são significativamente modificadas no contexto moderno, tanto através do aparecimento das empresas de economia mista e da expansão do Estado nacional brasileiro, quanto da relativa democratização do ensino. Com esse movimento, sedimenta-se a admissão no serviço público por meio de concurso, processo este que vai ter um impacto decisivo na vida de estratos sociais que, até então, dificilmente teriam acesso

a ascensão social e classes socais e grupo de prestígio. Salvador, EDUFBA, $2^{a}$ ed., 1996, p.166.

8 BACELAR, Jéferson. A hierarquia das raças: negros e brancos em Salvador. Rio de Janeiro, Pallas, 2001. 
Fora do jogo

ao ensino superior, e, por conseqüência, as possibilidades de transformar sua posição social, ocupando posições sociais distantes das famílias.

Os mecanismos mediante os quais se recruta os servidores públicos modificou-se completamente, e o critério de seleção por meio de concurso tem se constituído, efetivamente, como mais democrático, uma vez que reduz não só as prováveis ações discriminatórias que ocorrem em outros setores do mercado de trabalho, como ameniza a importância das redes e dos contatos sociais, as famosas "indicações" que favorecem o acesso ao trabalho. Entretanto, desconhecemos os critérios que operam na promoção no interior do serviço público.

Numa pesquisa anterior ${ }^{9}$, constatei que as estratégias de ascensão utilizadas pelo grupo pesquisado (profissionais liberais) foram a escolaridade elevada e a associação entre emprego público e privado, recursos que marcaram as trajetórias da maioria dos entrevistados. Com relação aos empresários/empregadores negros com baixa escolaridade, o estabelecimento de um empreendimento ocorre na maioria das vezes através do recurso proveniente da demissão do emprego formal, em que o FGTS é utilizado para a abertura do próprio negócio. Os empresários com maior escolaridade iniciam neste ramo através da formação de pequenas sociedades, com recursos próprios que não são, necessariamente, provenientes do FGTS, mas de economias pessoais. É importante destacar que nenhum deles contou com apoio do capital familiar.

Independente dos mecanismos de mobilidade, vale a pena destacar que a ascensão social dos negros tem sido historicamente orientada a partir do uso de estratégias individuais. Os negros que ascendem são vistos, quase sempre, como exceção à regra do grupo, majoritariamente representados nos estratos inferiores da hierarquia profissional. Algumas pesquisas mais recentes apontam

9 Figueiredo, A. Novas elites de cor... Op. cit. 
a importância da família no percurso ascensional. ${ }^{10}$ Azevedo observou que "a ascensão social dos escuros como indivíduos é freqüente e fácil de verificar. Como grupo, no entanto, as pessoas de cor vêm ascendendo mais dificultosamente". ${ }^{11}$

Ainda que centrada mais especificamente no emprego público, estas breves referências objetivam demonstrar como as estratégias de mobilidade social empregadas pelos negros foram modificadas nas últimas décadas - sendo que no passado eram caracterizadas por uma relação de dependência com indivíduos ou famílias brancas. Ao que parece, a relação com os brancos que possibilitava a mobilidade era a mesma que permitia o ingresso, ainda que marginalmente, no mundo dos brancos. Argumento que o uso de mecanismos de mobilidade mais autônomos - que não envolvam, necessariamente, uma relação de subordinação, subserviência e, conseqüentemente, a sensação de ter uma dívida para com alguém - influenciam a percepção sobre o significado da mobilidade social, do preconceito e da discriminação racial.

Em que pese a relevância dos dados acerca das desigualdades no acesso à educação e nos desníveis de renda entre os trabalhadores brancos e negros brasileiros, ainda permanece a crença de que os negros, membros da classe média, são vistos e tratados como brancos. Sabemos que esta afirmação só pode ser considerada relativamente verdadeira, pelo fato de as relações raciais no Brasil serem personalizadas. Assim, dentro de um espaço específico de reconhecimento do status que detêm, a exemplo do local de trabalho e de moradia, alguns negros podem ser tratados como tendo um poder aquisitivo e um status comparáveis aos de um branco. Ora, basta haver alguma confusão ou mal-entendido para que a sua posição econômica $e$ social seja irrelevante e a sua condição racial seja destacada, ou o

\footnotetext{
${ }^{10}$ TeiXeIRA, Moema de Poli. Negros em ascensão social: trajetórias de alunos e professores universitários no Rio de Janeiro. Tese de doutorado, Rio de Janeiro PPGAS/Museu Nacional, 1998.

${ }^{11}$ Azevedo, T. As elites de cor ... Op. cit, p.164.
} 
Fora do jogo

termo negro e outras denominações sejam utilizados em tom pejorativo, acusatório. Além disso, ao ultrapassarem estes espaços restritos de reconhecimento, quase sempre estes indivíduos são vistos como negros e tratados do modo como se trata, em geral, os negros no Brasil, sempre com certa desconfiança. Isso ocorre quando os entrevistados querem desfrutar de sua posição econômica elevada, ou seja, no consumo de bens e serviços considerados caros ou luxuosos. ${ }^{12}$

Constantemente citado nas ocasiões em que se discorre sobre a discriminação racial no Brasil, e sobre a dicotomia entre raça e classe, Pelé é um caso emblemático. O tratamento dispensado a Pelé não resulta da sua posição sócio-econômica, mas do reconhecimento público que ele tem, mesmo para as pessoas consideradas racistas. Pelé é considerado um "negro especial", o êxito na profissão o tornou um símbolo do futebol $e$ da identidade nacional. Por isso mesmo, este não parece ser um bom exemplo.

Tomando como ponto de partida esta constatação, passo a analisar os exemplos contidos na fala dos entrevistados, pessoas relativamente anônimas, que mencionaram terem sido vítimas do preconceito e da discriminação racial. ${ }^{13}$ Ao que parece, pertencer à classe média, longe de ser um antídoto contra a discriminação $e$ o preconceito racial, expõe as pessoas negras a situações de maior

\footnotetext{
${ }^{12} \mathrm{Na}$ minha dissertação de mestrado dediquei um capítulo para entender o conceito de embranquecimento social utilizado por diversos autores, assim como observei os diversos exemplos de discriminação racial citados pelos entrevistados. Guimarães atesta que as pessoas mais escolarizadas e moradoras das grandes cidades são as que mais denunciam terem sido vítimas do racismo. FiGUEIREDO, A. Novas elites de cor... Op. cit.; GuIMARÃES, Antônio Sérgio. Racismo e restrições dos direitos individuais: a discriminação "publicizada". Estudos AfroAsiáticos, no 31, 1997, pp.51-78.

${ }^{13}$ Considerando os limites de um artigo, utilizo diversos exemplos sobre a discriminação e o preconceito racial, inclusive aqueles que não são considerados como tais pelo entrevistado, para possibilitar que o leitor tenha uma visão mais ampla acercado tema.
} 
vulnerabilidade $e^{14}$, uma vez os espaços sociais que convivem são majoritariamente freqüentados por brancos.

Desse modo, eles são levados a refletir sobre a sua condição étnico-racial e sobre os limites da ideologia racial brasileira. Como argumentarei mais adiante, tanto o reconhecimento sobre o ser negro quanto a tentativa de articulação de um discurso identitário surgem na fase adulta - como resultado do contato com o "mundo dos brancos" -, restando apenas a possibilidade da assunção de uma identidade étnico-racial tardia.

Decerto que as interpretações diante de práticas discriminatórias podem variar e talvez um bom indicador seja a posição social dos indivíduos; uma pessoa pobre que é discriminada pode atribuir o tratamento desigual ao fato de ela estar mal vestida para a ocasiáo, pode creditar ao fato de que ela não soube se expressar corretamente, e até mesmo porque ela não soube se comportar devidamente. Enfim, muitas vezes essas pessoas acabam, de uma forma ou de outra, assumindo para si a responsabilidade. Inversamente, a maioria das pessoas negras de classe média sabe que estão bem vestidas, que têm renda e, às vezes, escolaridade suficiente para não serem tratados inadequadamente, com base em estereótipos que estabelecem o "lugar dos negros".

É importante observar que a abordagem sobre o preconceito e a discriminação racial só foi introduzida após a primeira fase da entrevista, quando os entrevistados relatavam livremente suas trajetórias, enfatizando os aspectos que eles consideravam relevantes em suas vidas. Com isso, tencionava entender se, e quando, o discurso racial era mencionado em seus relatos. Freqüentemente, eles começavam descrevendo a infância de uma criança pobre; somente na fase adulta de suas vidas falavam de si como um homem ou uma mulher negra.

${ }^{14}$ Refiro a maior vulnerabilidade do ponto de vista simbólico que se diferencia da violência física sofrida pelos negros pobres. 
Fora do jogo

A pergunta inicial sobre a discriminação racial foi: "o sr. (a) já sofreu algum tipo de discriminação racial?". Alguns disseram que não, pois são suficientemente conhecidos em Salvador, mas citaram exemplos de discriminação ocorridos em outras cidades. Outros disseram que não e citaram casos envolvendo pessoas próximas. Parcela significativa dos entrevistados respondeu que não num primeiro momento; contudo, ao insistir um pouco mais sobre este assunto, eles acabam mencionando um fato que consideraram corriqueiro, quotidiano, por exemplo, o fato de serem confundidos com os trabalhadores da empresa. Isso não seria grave se eles não tivessem afirmado ser o dono, gerente ou administrador; mesmo assim, algumas pessoas insistiam: "Eu quero falar com o gerente". Esta demanda podia ser tanto dos vendedores, representantes de produtos que a empresa utiliza, ou dos próprios clientes.

Todavia, nenhum dos entrevistados esboçou algum tipo de resposta a esta situação, que parecia ser, no mínimo, constrangedora. Eles falavam com um tom irônico, pois o fato já havia acontecido tantas vezes que não mais o consideravam relevante. O exemplo de uma entrevistada é bastante ilustrativo: na época da formatura da irmã caçula, ela, a irmã e uma amiga se dirigiram ao prédio de uma costureira, localizado numa zona nobre de Salvador; ao entrar no elevador, uma senhora se dirigiu a elas e perguntou se tinham uma amiga como elas para trabalhar na casa dela. A irmã, formada em medicina pela UFBa, sentiu-se extremamente agredida, enquanto as outras riram do "equívoco" cometido pela senhora. Ficou evidente, em seu relato, que elas perceberam tal confusão como uma prática discriminatória; afinal de contas, foram confundidas com empregadas domésticas. Entretanto, isto não foi o suficiente para que revidassem.

Outros demoram a perceber que o tratamento desigual a eles dirigido tenha sido efetivamente uma discriminação pautada em bases raciais. Convidada para participar num curso de culinária em São Paulo, a entrevistada relata: 
Angela Figueiredo

É um hotel em São Paulo, lindo, cinco estrelas. Eu tive que ficar hospedada nesse hotel... eu acho que eles nunca tinham hospedado negro, eu acho que negro no hotel era só para limpar chão. Então entra uma negra, metida a besta, que diz que ia dar aulas ali, ninguém acreditou. Aí eu prontamente quando eu cheguei, eu já sabia que a minha diária estava lá, eu mostrava ao cara que eu era Antônia e ele não achava no computador, e eu sei que estava lá. Aí eu fui educada, ele me fez procurar, o miserável, naquele lugar imenso, me fez andar aquilo tudo. Subir em elevador, descer, sair em buracos que eu nem sabia eu saía, saía em salões que não tem nada a ver... A gente chegou dez horas $e$ andou até quatro horas, e eu voltava no salão, falava $e$ nada, ele dizia: "não tem esse nome, eu nunca vi esse nome"... eu já irritada disse: "Meu filho, eu posso ligar? Você me liga para esse número..." Aí ele pegou o telefone e botou no balcão para eu ligar. Aí eu senti que era preconceito; até aí eu não tinha sentido que era preconceito, só tinha engolido como sacanagem! (Antônia)

\section{Vejamos um outro exemplo:}

Já aconteceu um lance comigo que eu não achei nem que fosse preconceito, eu acho até que foi uma falta de... um mal-entendido. Eu entrei nas Lojas Americanas lá no Rio, aí eu fiz umas compras e quando fui passar o cheque, aí a menina não entendeu o código da minha cidade que é 071 , Salvador. Aí eu dei o telefone para ela, ela aí ligou para checar se estava certo o telefone, mas aí ela ligou com o código de São Paulo, do Rio. Aí a moça disse assim: "Não, eu nunca tive uma empregada com esse nome"... Aí o gerente chegou junto de mim, aí ela olhou para mim e falou "Senhora, qual é o seu telefone mesmo?". Eu disse: meu telefone é $071 . . . "$, aí dei o código, quando eu dei o código, o gerente já estava junto de mim todo apavorado, porque eles estavam pensando que eu ia achar que era discriminação. Jamais, eu senti que foi um mal-entendido. (Dinalva) 
Fora do jogo

Esta fala é muito curiosa; antes mesmo de relatar o fato, a entrevistada afirma que o que se passou naquela ocasião foi um mal-entendido; em seguida, ela fala da experiência ocorrida no Rio de Janeiro e diz que a funcionária das Lojas Americanas, ao ligar para confirmar o número do telefone dela, ouviu a seguinte resposta: "eu nunca tive uma empregada com esse nome". Mas, se a funcionária ligou para confirmar o número do telefone, de onde surgiu a referência à empregada doméstica? Será que foi uma interpretação da entrevistada ou será que a funcionária perguntou sobre uma empregada doméstica? Num terceiro momento, aparece a figura do gerente, que já entra na situação "...apavorado, porque eles estavam pensando que eu ia achar que era discriminação". Em todos os momentos do relato surge a referência direta ou indireta à discriminação racial - direta, no caso do gerente, e indireta, quando a entrevistada é confundida com uma empregada doméstica.

As pessoas que praticam a discriminação racial são sempre vistas como mal-educadas, mal-informadas, mas nunca os entrevistados as consideram racistas.

Então o povo é isso ai, se alguém discrimina eu vejo que essa pessoa não está preparada, não é uma pessoa que tem formação, que tem educação. ...Acontece às vezes com pessoas que têm educação, que têm formação, mas aí já parte de uma índole, porque aquela pessoa foi criada com a discriminação no meio e faz aquilo que aprendeu. (Armando)

Outro entrevistado considera como manifestação de discriminação racial, porém tolerável, a surpresa com que os novos clientes o recebem na primeira reunião; ele enfatiza todo o tempo que a expectativa deles é de que um contador indicado por um amigo branco seja necessariamente branco.

Entrevistador: Agora me diz uma coisa, nesse período todo você, em algum momento, sendo contador, tendo que lidar 
com pessoas que têm poder aquisitivo elevado, donos de empresas, já houve algum conflito, alguma tensão em termos raciais?

Entrevistado: Não, raciais, não. Acho que eles aturam, a gente sempre acha que o branco está de pé atrás... de pé atrás. Muitas vezes você sente que eles não esperam por mim, às vezes, supondo, se alguém fizer uma indicação "eu tenho um contador bom" alguma coisa assim, "tem resolvido os problemas aqui" acho que eles sempre imaginam na cabeça deles um branquinho, de óculos redondinho, de paletó e gravata. Imagina, na hora que as pessoas estão falando, acho que eles moldam essa imagem. Quando você chega inicialmente, acho que todos se sentem surpreendidos porque chegou um negro. Isso eu já percebi.

Entrevistador: Desapontamento, você acha?

Entrevistado: Não sei se é desapontamento, eles olham assim como quem diz assim "Esse?", entendeu?

Entrevistador: Mas isso, de algum modo, você acha que mexe com a credibilidade deles na sua competência profissional?

Entrevistado: Nas minhas experiências não, porque deve passar muita coisa na cabeça na hora, não sei bem o que passa na cabeça deles, mas eu sinto que tem alguma coisa assim. É como se eles não esperassem que fosse chegar um negro. Eles esperavam que chegasse ali um contador branco, disso eu tenho quase certeza, ainda mais quando você lida com as empresas grandes.

Contudo, esta surpresa manifestada inicialmente não tem prejudicado os contratos e as efetivas relações de trabalho.

(...) o intolerável ainda não teve. Acho que pode acontecer a qualquer momento, mas ainda não teve. Esse tolerável acontece o tempo inteiro, você percebe claramente. (...) Eu vou ter uma reunião segunda-feira com um empresário que eu já conheço, mas eu tenho certeza que o que eu já conheço está me indicando para outro cliente. Eu acho 
Fora do jogo

muito pouco provável que ele tenha feito um comentário dizendo: "Ah, eu estou te indicando um contador, olha ele é negão, mas é batata." (...) Agora, eu tenho certeza absoluta, $90 \%$ de chance de que o amigo que ele está me apresentando é branco. Eu sempre pensei, eu sempre esperei essa expectativa do baque de ser negrinho, na hora que você chega, mas assim, de um empresário chegar assim, "eu não vou te contratar porque você é negão". Porque, na verdade, esse problema de ser desse racismo brasileiro, como é que as pessoas são racistas e dizem que não são, manifestam com seus atos assim muito... é que faz com que não gere essa expectativa de ser dessa forma. Você sabe que eles não tomam essa atitude dessa forma, eles vão até, podem até não querer, ele vai tratar bem ali, vai sair dali, uma reunião formal, tudo bem, mas vai, digamos (...) uma frieza maior de um lado, você é frio do outro lado também, e vamos ter nossa conversa técnica. (Joseval)

É também constante a referência à desconfiança com que os entrevistados dizem ser observados quando estão dirigindo seus carros, mesmo quando o tema abordado não é o racismo.

Eu acho que as pessoas... eu não sei, eu não ligo não, eu deixo passar despercebido. Está na cabeça de cada um, o importante é o que está na minha consciência, eu deixo passar despercebido, se eu passo no carro, com um carro novo e alguém olha. ...Meu carro é um L 200, até outro dia eu estava com uma BMW, eu não ligo não... se alguém me aponta eu viro o rosto, olho para outro lado. (Armando)

\section{A outra referência diz respeito à compra de um carro.}

Entrevistador: Você falou um pouco da sua relação com a cultura negra. Você já foi alvo de discriminação?

Entrevistado: Já, eu fui um caso até que saiu na revista Veja, fui alvo nacional disso, o que aconteceu comigo? Em 
Angela Figueiredo

1995 eu vi, eu estava lendo uma reportagem sobre aquela parte de automóveis, da Folha de S. Paulo, eu sou assinante da Folha, domingo em casa, e lá tinha um Mustang, e eu tinha um sonho de ter um Mustang (...) aí eu vi que tinha dois carros, dois Mustang conversíveis, um GT, motor 5.0 custava 72 mil dólares naquela época. E aquilo me deixou excitado, vou me dar esse carro de presente, peguei uma poupançazinha... "amigo, eu quero o carro, quanto é que custa? ah, eu não tenho esse dinheiro todo". (...) Quando no dia 16 de dezembro, já estava pago o carro desde o dia 10, a Cell Star, que é uma das empresas que eu revendia aqui, que naquela época era distribuidora da Motorola, me convidou para uma festa de Natal deles lá em São Paulo... e eu fui lá no Morumbi para ver o carro. Quando cheguei lá, neguinho, nordestino, aquela coisa, sabe que em São Paulo a discriminação é muito maior, aí passou uma moça eu perguntei: "minha filha, você pode me atender, por favor? Eu queria falar com o senhor Wellington, que é o supervisor". Ela me disse "ele não está, foi almoçar". "Que horas ele volta?", "ah, não sei" me deu as costas e foi embora, e eu estava junto com uma pessoa da Cell Star, Marcelo, um cara louro, e eu, minha roupa simples, uma camisinha de manga comprida, como eu gosto de andar; aí quando ela voltou de novo, "você pode me dar uma atenção, eu queria falar. E o gerente de vendas está aí?", ela já olhou... falou assim "como é o nome do senhor?", disse "ah, o senhor que comprou", aí me botou numa sala especial, lá vem salgadinho, uísque, veio o diretor me cumprimentar, o carro estava lá naquela coisa, gente como o diabo, era o primeiro Mustang GT que chegava no Brasil, uma coisa assim portentosa, não é? ...É, você sabe, a discriminação quando chega na grana acaba, não é?

A postura hegemônica no meio acadêmico acerca da prevalência do preconceito de classe sobre o preconceito racial nas relações raciais brasileiras também está presente na fala de alguns entrevistados. Algumas vezes os informantes oferecem uma 
Fora do jogo

interpretação que nos leva a considerar que eles acreditam que, no Brasil, o preconceito ainda é de classe, ou o problema do tratamento diferenciado oferecido aos negros resulta da falta de recursos financeiros. Contudo, ao indagar mais sobre isso, o entrevistado responde:

Entrevistado: Existe a questão da raça, porque no Brasil, se você é rico e negro está tudo livre, se você é pobre e negro está tudo fechado, se você é pobre e branco está tudo fechado. Então o Brasil é o que eu falei antes, a gente vive.

Entrevistador: É a mesma coisa ser rico e negro e ser rico e branco?

Entrevistado: Não é tão igual quanto o branco e rico, porque as pessoas querem saber por que estamos ali. Exemplo, quando eu participava de rodas mais sociais, estava compartilhando com rico, o pessoal queria saber como eu estava ali, ficavam muito curiosos. Eu descia num hotel cinco estrelas, o pessoal esperava que eu falasse inglês, mas quando eu começava a falar "baiano"... Descia de um avião, pegava um traslado no meio de todos os brancos e todo mundo ficava pensando que a gente era americano ou africano, sempre que eu estava com algum colega do meu nível social... A gente ingressava no mesmo hotel, por exemplo, em viagens de Fórmula I, viagens de salões de automóveis, as pessoas ficavam querendo saber por que a gente estava ali, não dava para vir perguntar, mas sempre estavam curiosas. (Derivaldo)

A fala deste entrevistado demonstra a curiosidade $e$ a desconfiança com que ele é observado nos espaços sociais freqüentados por membros da classe média e alta. Ainda que em nenhum momento lhe tenham perguntado: "quem é você?", ou, "por que você está aqui?", ele parece antevê-la. É curioso notar como o entrevistado analisa a expectativa daqueles que o encontravam: "Eu descia num hotel cinco estrelas, o pessoal esperava que eu falasse inglês, mas quando eu começava a falar 
Angela Figueiredo

'baiano'!...." É como se o fato de ser negro e freqüentar espaços associados a classes mais abastadas só pudesse ser justificado no caso de não ser brasileiro. Afinal, a representação sobre o lugar do negro na sociedade brasileira jamais permitiria uma associação diferenciada entre cor e classe.

A partir dos diversos exemplos, dei-me conta que, mesmo quando eles reconhecem que estão sendo vítimas do preconceito racial, parecem não reagir diante disso. Quando a discriminação é praticada por um cliente, não revidar pode ser uma estratégia já que, em última instância, o empreendimento necessita vender para obter lucro; mas qual o motivo que os leva a tomar a mesma atitude quando a discriminação é praticada por outras pessoas, fora dos espaços de trabalho?

Diante disso, comecei a investigar não mais se eles haviam sido discriminados. Procurei entender como, quando e porque as pessoas reagem com gestos, agressões físicas e verbais ou recorrem a ações judiciais contra atitudes discriminatórias. Reformulada a pergunta, a questão era: "O que levaria o sr(a) a tomar uma posição frente a uma atitude discriminatória?"

Dessa questão saíram diversas respostas. Em poucos casos, os entrevistados disseram não recorrer ao Poder Judiciário devido à morosidade da justiça brasileira; outros entrevistados disseram que não gostariam de se envolver com escândalos públicos. Um entrevistado mencionou que só tomaria uma atitude se quem discrimina estivesse no mesmo patamar que ele, referindo-se ao nível social e econômico; a grande maioria observa que, freqüentemente, quem discrimina são os funcionários e não o proprietário, não valendo a pena se indispor com o funcionário afinal de contas, "o coitado pode até perder o emprego". Reagir frente à discriminação também pode estar relacionado a terceiros, como relatou um dos entrevistados, que afirmou que tomaria uma atitude reativa se o fato tivesse ocorrido com pessoas que ele considera incapazes de se defender, a exemplo dos filhos e alguns membros de sua família. A probabilidade de que ele interceda em causa própria é menor que se o fato tiver ocorrido com aqueles 
Fora do jogo

que ele considera mais frágeis, efetivamente incapazes de tomar uma atitude.

Nesse sentido, é importante entender como e quais as circunstâncias em que o tema do racismo é tratado em casa. Diferente da sua experiência educacional em escolas públicas, todos os entrevistados matriculam os seus filhos em boas escolas particulares de Salvador, majoritariamente freqüentadas por brancos. Sabemos também que o espaço de sociabilidade não se reduz à escola. O contato dos filhos com as crianças brancas desperta nos pais a necessidade de precavê-los, caso ocorra algum tipo de brincadeira, piada ou exclusão, cujo mote seja a cor. Eles não querem que os seus filhos sejam humilhados; por isso, sentem necessidade de dialogar com eles sobre um tema até pouco tempo considerado tabu: o preconceito racial. Contudo, não há unanimidade nas respostas acerca de como se deve reagir a práticas discriminatórias, e em alguns casos se aconselha 0 silêncio. Recomenda-se que é melhor não reagir, ou seja, se é comum abordar o tema da discriminação e do preconceito racial com os filhos, o mesmo não podemos dizer com relação às respostas oferecidas a esta situação. Vejamos.

Referindo-se ao diálogo sobre a discriminação racial com os filhos, um entrevistado comenta:

Entrevistado: Eu converso bastante com meus filhos, porque eles estudam em um colégio que $99 \%$ são brancos, o Diplomata. E eu sempre digo isso, de ter que deixar indiferente, se alguém está te discriminado é porque alguém está incomodado, faz de conta que não viu.

Entrevistador: Mas eles chegam a falar alguma coisa que houve na escola?

Entrevistado: Comentam, mas eu sempre passo para eles que tem que deixar, não dar respostas, não discutir; se ofender, vai à direção do colégio e comunica que eles tomam uma providência. (Armando) 
Angela Figueiredo

Outro entrevistado diz:

Entrevistado: Converso, e não induzo de maneira nenhuma à prática do racismo. Mas falo que eles devem procurar se proteger e não deixar que isso aconteça, que eles têm que se impor, que fora da escola, na vida as oportunidades são diferentes, então tem que procurar correr atrás e não perder tempo. Eu falo isso para meu filho todos os dias, qualquer dia desses ele entende.

Entrevistador: Mas seu pai falava dessas coisas para você quando você era criança?

Entrevistado: Ele não falava, mas mostrava, não falava como estou aqui te falando, mas sempre foi uma pessoa que trabalhou muito, sempre foi uma pessoa voltada muito para a família. E eu procuro fazer a mesma coisa. (Eraldo)

Não podemos esquecer a diferença entre os contextos sociais em que pais e filhos foram criados. Temas que até há pouco tempo atrás só eram tratados no âmbito restrito da academia e dos movimentos negros, hoje estão presentes na imprensa e na mídia televisiva em horários considerados nobres. Como demonstrei, todos os entrevistados mencionam o racismo existente na sociedade brasileira; contudo, isso não significa que todos reajam frente às práticas discriminatórias. Ainda existe um grande hiato entre o reconhecimento da discriminação racial $e$ a tomada de atitudes frente às práticas discriminatórias.

\section{Negritude e modernidade tardia,} ou modernidade e identidade tardias

Até agora meu esforço foi demonstrar a falácia a crença de que os negros em posições sociais mais elevadas são vistos $e$ tratados como brancos. Doravante, abordarei o tema da identificação étnica/racial para os negros que ocupam posições sociais mais elevadas, como resultante da experiência de estar "fora do lugar", que não necessariamente se convertem em 
Fora do jogo

estratégias políticas coletivas, mas parece estar em perfeita consonância com as modernas teorias sociais.

Adoto, aqui, uma posição contrária àqueles que acreditam na impossibilidade da assunção de uma identificação, uma identidade étnico/racial tardia. $\mathrm{O}$ argumento dos autores que acreditam que isto constitui um contra-senso pode ser sumariamente apresentado em três pontos: a) a importância da identidade na constituição da personalidade dos indivíduos; b) a centralidade do conceito de cultura e o essencialismo em torno do mesmo; e c) a rejeição ao hibridismo cultural. ${ }^{15}$ No que se refere especificamente aos negros, parece haver uma crença na incompatibilidade da experiência negra na modernidade.

Além dos clássicos que introduziram o termo identidade nas Ciências Sociais em outros contextos ${ }^{16}$, os poucos trabalhos realizados no Brasil que enfatizam o indivíduo são oriundos da psicologia e neles encontramos a referência às conseqüências psíquicas dos estereótipos negativos sobre os negros vigentes na sociedade brasileira. ${ }^{17}$ Ferreira, no cuidadoso levantamento bibliográfico de 4.911 títulos na área de psicologia em São Paulo, no período entre 1987 a 1997, concluiu que apenas 12 tratavam dos afrodescendentes e nestes apenas três se detinham no tema da identidade. ${ }^{18} \mathrm{O}$ autor então interroga: "Seriam as variáveis raça

15 SPTIZER, Leo. Vidas de entremeio: assimilação e marginalização na Áustria, no Brasil e na África Ocidental 1780-1945. Rio de Janeiro, EDUERJ, 2001.

${ }^{16}$ EPSTEIN, A. L. Ethos and Identity: three studies in ethnicity. London, Tavistock, 1978. ERIKSEN, Thomas Hylland. Ethnicity \& Nationalism. London, Pluto Press, 1993.

${ }^{17}$ BaraúnA, Lia Maria Perez Botelho. À Flor da pele. In: CARONE, Iray e Bento Maria Aparecida Silva. (orgs.) Psicologia social do racismo: estudo sobre branquitude e branqueamento no Brasil. Petrópolis, Vozes, 2002, pp.131-146.

${ }^{18}$ Ferreira analisa a construção da identidade afrodescendente em quatro estágios; 1 - submissão, idealização do mundo branco com escudo; 2 - estágio de impacto, descoberta do grupo étnico-racial de referência; 3 - militância, construção de uma identidade afrocentrada; e 4 - articulação, abertura para a alteridade. FERREIRA, Ricardo Franklin. Afro-descendente: Identidade em construção. Rio de Janeiro, Pallas, 2000. 
e origem étnica consideradas como não relevantes no estudo do homem?"

Se for este o caso, então os psicólogos não estariam levando em conta as diferenças efetivamente existentes desta população. Creio não ser uma opção absurda, pois tal postura estaria alinhada com o apregoado discurso oficial, ao qual o psicólogo também está submetido enquanto cidadão, tendo sua identidade também construída em torno da idéia da ausência de preconceito no Brasil, de tratamento igualitário para todas as pessoas e de iguais oportunidade de mobilidade social para todos". ${ }^{19}$

De fato, o debate sobre as relações raciais no Brasil tem deixado à margem a discussão sobre a constituição dos indivíduos nas sociedades modernas. Ao contrário, como o diálogo é, na maioria das vezes, estabelecido com a tradição, há uma tendência a priorizar o coletivo, a experiência coletiva dos negros na sociedade brasileira. Como nos ensina Giddens, uma das características da modernidade tardia é a complexa variedade de opções que os indivíduos encontram na conformação dos estilos de vida, em oposição às escolhas estruturadas presentes nas sociedades tradicionais. Por estilo de vida entende-se

(...) um conjunto mais ou menos integrado de práticas que um indivíduo abraça, não só porque essas práticas preenchem necessidades utilitárias, mas porque dão forma material a uma narrativa particular de auto-identidade. ${ }^{20}$

Se levássemos ao extremo a argumentação de Giddens, concluiríamos que a importância da identificação étnico/racial na

\footnotetext{
${ }^{19}$ ID., IB., p.60.

${ }^{20}$ GidDENS, Anthony. Modernidade e Identidade. Rio de Janeiro, Zahar, 2002, p.79.
} 
Fora do jogo

construção da auto-identidade reflexiva na modernidade tardia resulta de mais uma dentre tantas outras escolhas. ${ }^{21}$

Mesmo que Giddens aborde tanto as macro-transformações que caracterizam a modernidade tardia ou a alta modernidade. quanto aquelas que repercutem na construção da auto-identidade reflexiva, definitivamente ele não menciona as questões relativas a forma como os indivíduos membros de minorias étnicas ou racialmente diferenciados fazem suas escolhas na construção da auto-identidade nos contextos marcados não só por possibilidades de escolhas individuais, mas também por estereótipos, estigmas e exclusão. Desse modo, o autor refere-se não somente a uma modernidade homogênea, com seus marcos distintivos das sociedades tradicionais como trata de um indivíduo genérico. ${ }^{22}$

Ainda que não se refira à constituição dos indivíduos, pois sua análise é direcionada aos sujeitos coletivos, Manuel Castells estabelece o elo entre a macroteoria, a sociedade em rede e a construção das identidades coletivas num contexto marcado por relações de poder. Nesse sentido, seria oportuno observar que as

\footnotetext{
${ }^{21}$ Para Giddens, a modernidade alta ou tardia é uma ordem pós-tradicional caracterizada pela transformação do tempo e do espaço, em conjunto com os mecanismos de desencaixe (o deslocamento das relações sociais dos contextos locais e sua rearticulação através de partes indeterminadas do espaço-tempo), que afasta a vida social de influências, e práticas e preceitos preestabelecidos e por uma reflexividade institucional amadurecida. "A reflexividade da modernidade deve ser distinguida do monitoramento reflexivo da ação intrínseco a toda atividade humana. Ela se refere à suscetibilidade da maioria dos aspectos da atividade social, e das relações materiais com a natureza, à revisão intensa à luz de novo conhecimento ou informação". GIDDENS, Anthony. Modernidade e Identidade... Op. cit., p.26.

${ }^{22}$ Para uma análise crítica da relação entre desigualdade e modernidade em Giddens, ver SOUZA, Jessé. Multi-Culturalismo e Racismo. Uma Comparação Brasil-Estados Unidos. Brasília, Paralelo 15, 1997; Domingues faz uma análise da modernidade brasileira à luz dos conceitos de desencaixe e de reflexividade. DOMINGUES, José Mauricio. Desenvolvimento, modernidade e subjetividade. In: MAIO, Marcos Chor e VILlAS BÔAS, Gláucia. (orgs.) Idéias de modernidade e a sociologia: ensaios sobre L. A. Costa Pinto. Porto Alegre, Editora da UFRGS, 1999, pp.71-86.
} 
Angela Figueiredo

escolhas mencionadas por Giddens ocorrem numa sociedade marcada por fluxos, redes, escolhas, desigualdades, estigmas $e$ discriminação. Referindo-se a marcha de um milhão de homens realizada em Washington, em 1995, Castells argumenta que essas novas manifestações de identidade política resultam de um princípio mais religioso do que étnico e que seu impacto não está fundamentado na identidade, mas sim na consciência da perda dessa identidade. A hipótese do autor é que:

(...) a etnia não oferece as bases para os paraísos comunais da uma sociedade em rede por estar fundamentada nos vínculos primários que perdem o sentido, quando extraído do seu contexto histórico, como base para a reconstrução do significado em um mundo de fluxos e redes, de novas combinações de imagens e novas atribuições de sentidos. (...) em meio a comunas culturais e unidades territoriais de autodefesa, as raízes étnicas são distorcidas, divididas, reprocessadas, misturadas, estigmatizadas ou recompensadas de maneira distinta, de acordo com uma nova lógica de informalização/globalização de culturas $e$ economias que produzem compostos simbólicos a partir de identidades não claramente discerníveis. Raça é um fator muito importante, mas dificilmente se pode dizer que seja ainda capaz de criar significados. ${ }^{23}$

Acrescentaria a estas duas referências a reflexão de Stuart Hall sobre a descentralização dos sujeitos pós-modernos, caracterizada pelo deslocamento de um "sentido de si" estável. Essa breve referência aos autores que tratam do tema da identidade individual e coletiva na modernidade traz à tona duas importantes questões que darão suporte à minha argumentação: as inúmeras possibilidades de escolha na construção da autoidentidade reflexiva na modernidade tardia e a dificuldade de

${ }^{23}$ CASTells, Manuel. O Poder da Identidade: A era da informação, economia, sociedade e cultura. Rio de Janeiro, Paz e Terra, 1999, p.78. 
Fora do jogo

acionar a solidariedade racial na construção da identidade coletiva na sociedade em rede.

Com relação ao hibridismo cultural, Hall argumenta que na modernidade tardia, na era da globalização, é inevitável para aqueles que vivem em novas diásporas, criadas pelas migrações pós-coloniais

(...) renunciar ao sonho ou ambição de redescobrir qualquer tipo de pureza cultural "perdida" ou de absolutismo étnicos (...) Eles devem aprender a habitar no mínimo duas identidades, a falar duas línguas culturais, a traduzir e a negociar entre elas. ${ }^{24}$

Para o autor, a noção de tradução, em vez de tradição, será fundamental na criação de novas identidades na pósmodernidade.

Isto posto, retomo um trabalho anterior em que objetivei dar conta da importância atribuída à raça/cor na fala dos entrevistados. Na construção dos tipos ideais, defini três grupos distintos e empreguei em dois deles a mesma denominação utilizada por eles quando se referiam aos outros. Assim, os radicais e/ou militantes priorizavam a cor $e$ a raça nas suas experiências pessoais e também enfatizavam as questões relativas às desigualdades raciais, ao racismo e à discriminação racial na sociedade brasileira, freqüentemente, eles se referiam aos negros que não imputavam a mesma importância à cor/raça como alienados. Na utilização que fiz deste termo, os alienados foram os entrevistados que não atribuíram grande importância à cor ou à raça em suas falas; os assertivos destacavam o ser brasileiro. ${ }^{25}$

Tudo isso demonstra quão complexa é a realidade e que a atribuição de um único significado à identificação racial na construção da personalidade precisa ser matizada. Possivelmente,

${ }^{24}$ HALL, Stuart. Identidades culturais na pós modernidade. Rio de Janeiro, DP\&A Editora, 1997, p.96.

${ }^{25}$ FigueIREDO, Angela. Novas elites de cor... Op. cit. 
a identificação racial tem um peso maior para aqueles que reconstroem suas experiências destacando a cor/raça em suas trajetórias. Freqüentemente são pessoas que relembram do modo diferenciado/discriminado como foram tratados por vizinhos, colegas e professores durante a infância, recuperando as marcas que a discriminação racial deixou na sua personalidade; em se tratando das mulheres, o cabelo crespo ocupa um lugar central na memória e na reconstrução da exclusão de que foram vítimas na infância, seja na escola ou na própria família, talvez, por isso, para o ativismo negro, o cabelo crespo natural é um símbolo de afirmação da identidade, ao passo que para a maioria das mulheres que incorporaram as representações negativas sobre o cabelo crespos, o cabelo é, dentre os fenótipos negros, aquele que pode e deve ser manipulado. ${ }^{26}$

A maioria dos entrevistados dessa pesquisa iniciam os relatos mencionando a trajetória de uma criança nascida em uma família pobre e, dependendo da situação de privação material em que viveram, os relatos são mais ou menos densos, e mais ou menos longos. Os que migram do interior para a capital contam a saga da família numerosa $e$ as estratégias de sobrevivência utilizadas na capital - o emprego doméstico, entre as mulheres, $e$ o comércio informal, entre os homens, foram os recursos mais citados. Após este primeiro momento, eles falam sobre o que consideram como o primeiro emprego e sobre os tantos outros empregos que tiveram até serem empresários. Curiosamente, a cor só aparece nessas narrativas após a fase adulta e, freqüentemente, através de uma terceira pessoa, que se referiu ao fato de eles serem negros(as) num tom ofensivo, quase acusatório. Somente a partir disso é que começam a falar de si como pessoas negras. Apenas uma das entrevistadas citou o fato de ter sido vítima de discriminação racial na escola primária e, de fato, sua leitura sobre a raça/cor é diferenciada desde a infância.

${ }^{26}$ FIGUEIREDO, Ângela. Beleza pura: símbolo e economia ao redor do cabelo crespo. Monografia, UFBA, 1994. 
Fora do jogo

Resumindo o meu argumento neste ponto, considero que a importância da identidade étnico/racial/religiosa na construção da personalidade não é universal, e a primazia destas identificações na construção do indivíduo mantém uma relação com os valores da sociedade abrangente e com a trajetória da pessoa. ${ }^{27} \mathrm{E}$ em que pese os limites da ideologia brasileira, esta, efetivamente, tem inibido algumas dinâmicas e processos de emancipação que necessitam do discurso sobre a diferença.

As interpretações sobre o dilema da experiência negra na modernidade têm mais de um século. Du Bois mencionou a duplicidade que caracterizava a experiência dos negros norteamericanos "(...) duas almas, dois pensamentos, dois esforços irreconciliados; dois ideais que se combatem em um corpo escuro cuja força obstinada unicamente impede que se destroce" ${ }^{28}$ Por isso mesmo, Du Bois se refere à noção de dupla consciência, à impossibilidade que os negros têm de se ver com os próprios olhos.

O material derivado das entrevistas demonstra que se há uma dupla consciência para os entrevistados, ela não se revela em termos de nacionalidade (ser negro e/ou brasileiro), já que todos os entrevistados se consideram brasileiros, mas essa dupla consciência se manifesta no ser negro e membro de classe média, dado que a maioria das representações sobre os negros e sobre a cultura afro-brasileira se refere aos negros de classe baixa, restando pouco espaço para ser ao mesmo tempo negro e de classe média. ${ }^{29}$

\footnotetext{
${ }^{27}$ HANDLER, Richard. Is "identity" a useful cross-cultural concept?. In: GILLIS, John R. (ed.) Commemorations: The Politics of National Identity. Princeton, Princeton University Press, 1994.

${ }^{28}$ Du BoIs, W. E. B. As almas da gente negra... Op. cit., p.54.

${ }^{29}$ Para uma análise mais ampla do predomínio da nacionalidade frente a outras formas de identificação, ver SCHWARTZMAN, Simon. Fora de foco: diversidade e identidades étnicas no Brasil. Novos Estudos Cebrap, n 55, 1999, pp.83-96.
} 
Esta marca nacionalista da experiência dos negros no Brasil já foi mencionada por Bastide. ${ }^{30}$ Ao analisar comparativamente o movimento da negritude no Brasil e na França, ele identificou na negritude francesa um movimento cuja força era centrífuga, uma vez que era manifesto o desejo do retorno à África; enquanto no Brasil havia um desejo de integração, e não de retorno, o que ele caracterizou como uma força centrípeta. Outro exemplo provém das análises sobre a Frente Negra Brasileira, reconhecida como um movimento de integração de cunho nacionalista. ${ }^{31}$

Minha interpretação segue a trilha de alguns estudos que demonstram tanto existir uma intrínseca relação entre modernidade e negritude $e^{32}$, quanto ao fato de que as reivindicações étnicas tendem a ser manifestadas por aqueles que já perderam muito da sua própria cultura (entendida com a cultura dos pais) e, muitas vezes, mantêm uma relação próxima com a cultura dominante - seria até a sensação de estar se desligando de uma "cultura de origem" um dos motores dos processos identitários na modernidade tardia. ${ }^{33}$

Baseada nos relatos dos entrevistados - primeiros e, muitas vezes, os únicos membros da família a vivenciar o processo de mobilidade -, argumento que a experiência de ser membro da classe média parece ser extremamente importante para o reconhecimento da diferença entre o "nós" no sentido étnico/racial e os "outros", restando, portanto, somente a possibilidade de uma identificação tardia. Dito de outro modo, enquanto ocupavam a base da estratificação sócio-econômica, $e$ viviam em bairros pobres, esses indivíduos não se sentiam fora de

${ }^{30}$ BASTIDE, Roger. Negritude et intégration nationale. Afro-Ásia, no 12,1976 , pp.5-30.

${ }^{31}$ BACELAR, Jéferson. A hierarquia das raças ... Op. Cit. e HANCHARD, Michael George. Orfeu e Poder: Movimento Negro no Rio de Janeiro e em São Paulo. Rio de Janeiro, EDUERJ, 2001.

${ }^{32}$ Gilroy, Paul. O Atlântico negro. São Paulo, Editora 34, 2001.

${ }^{33}$ Roosens, Eugeen. Creating Ethnicity. The Process of Ethnogenesis. London, Sage, 1989. 
Fora do jogo

lugar e não eram vistos como tais. Situação oposta ao que ocorre quando eles passam a exercer cargos de comando, ocupar posição de destaque no mercado de trabalho, morar em bairros de classe média (que, mesmo em Salvador, são majoritariamente brancos), se dirigem aos espaços sociais freqüentados pela classe média, a exemplo de bares, lojas e restaurantes e quando matriculam os seus filhos em boas escolas particulares.

Assim como as identidades parecem se configurar na modernidade tardia, para os entrevistados dessa pesquisa a assunção da identidade negra definitivamente resiste ao uso da identidade no sentido político/coletivo, indo mais na direção de uma identidade que serve aos propósitos individuais, sobretudo, para ter acesso à cidadania plena, ou seja, a ênfase recai no aspecto do direito individual e não das estratégias coletivas de mobilização de recursos étnicos. Por mais desavisados que sejam, ou que não se preocupem com temas relativos à questão racial, ter os direitos restringidos pela crença na inferioridade $e$ incapacidade dos negros levam-nos de fato à problematização e à reflexão sobre as relações raciais no modelo brasileiro.

Do mesmo modo, a identificação racial é uma das tantas identidades que estes atores assumem na pós-modernidade. Ser membro da classe média é também estar sujeito a compartilhar com uma visão de mundo daqueles que ocupam a mesma posição social, ou como nos ensina Bourdieu, é estar sujeito ao mesmo habitus de classe. 